University of Nebraska - Lincoln

DigitalCommons@University of Nebraska - Lincoln

September 2007

\title{
Mutual fund flows and investor returns: An empirical examination of fund investor timing ability
}

\author{
Geoffrey C. Friesen \\ University of Nebraska-Lincoln, gfriesen2@unl.edu \\ Travis R. A. Sapp \\ lowa State University, trasapp@iastate.edu
}

Follow this and additional works at: https://digitalcommons.unl.edu/cbafacpub

Part of the Business Commons

Friesen, Geoffrey C. and Sapp, Travis R. A., "Mutual fund flows and investor returns: An empirical examination of fund investor timing ability" (2007). College of Business Faculty Publications. 48. https://digitalcommons.unl.edu/cbafacpub/48

This Article is brought to you for free and open access by the Business, College of at DigitalCommons@University of Nebraska - Lincoln. It has been accepted for inclusion in College of Business Faculty Publications by an authorized administrator of DigitalCommons@University of Nebraska - Lincoln. 
Published in Journal of Banking \& Finance 31:9 (September 2007), pp. 2796-2816; doi 10.1016/j.jbankfin.2007.01.024 Copyright (C 2007 Elsevier B.V. Used by permission.

http://www.sciencedirect.com/science/journal/03784266

Submitted September 11, 2006; accepted January 9, 2007; published online April 29, 2007.

\title{
Mutual fund flows and investor returns: An empirical examination of fund investor timing ability
}

\author{
Geoffrey C. Friesen* and Travis R. A. Sapp ${ }^{\dagger}$ \\ * College of Business, CBA 237, University of Nebraska-Lincoln, \\ Lincoln, NE 68588-0490, USA (email gfriesen2@unl.edu) \\ † College of Business, 3362 Gerdin Business Bldg., Iowa State University, \\ Ames, IA 50011-1350, USA (Corresponding author, email trasapp@iastate.edu)
}

\begin{abstract}
We examine the timing ability of mutual fund investors using cash flow data at the individual fund level. Over 1991-2004, equity fund investor timing decisions reduce fund investor average returns by $1.56 \%$ annually. Underperformance due to poor timing is greater in load funds and funds with relatively large risk-adjusted returns. In particular, the magnitude of investor underperformance due to poor timing largely offsets the risk-adjusted alpha gains offered by good-performing funds. Investors in both actively managed funds and index funds exhibit poor investment timing. We demonstrate that our empirical results are consistent with investor return-chasing behavior.
\end{abstract}

Keywords: mutual fund performance, fund cash flows, investor timing, fund clienteles

\section{Introduction}

Mutual fund investors can enhance their returns by selecting superior funds, advantageously timing their cash flows to the fund, or both. Gruber (1996) and Zheng (1999) suggest that investors have the ability to select funds with superior subsequent performance, 
a result referred to as the "smart money" effect. These studies find that the short-term performance of funds experiencing positive net cash flow appears better than those experiencing negative net cash flow. Sapp and Tiwari (2004), however, demonstrate that the smart money effect is explained by stock return momentum over the short term. Further research by Frazzini and Lamont (2006) suggests that poor fund selection decisions end up costing longer-term investors (those who do not rebalance quarterly) about $0.84 \%$ per year, a result they dub the "dumb money" effect.

In this paper we focus on the second possible method by which investors may enhance their returns, which is not explicitly addressed by the above studies. We ask whether mutual fund investors make good investment decisions strictly in the timing of their cash flows. That is, for any given fund, do equity fund investors put cash in and take cash out at the right time on average? It is well established that inflows to mutual funds are strongly correlated with past fund performance (Ippolito, 1992). Less clear is the impact of investor timing decisions on investor returns. And while numerous studies have examined the timing ability of mutual fund managers or other investment professionals, ours is the first comprehensive study to examine the timing ability of mutual fund investors using cash flow data at the individual fund level. ${ }^{1}$

We use the dollar-weighted return, derived as the internal rate of return of money under management, to measure the performance of fund investors, and time-weighted returns to measure the performance of the fund. Because a time-weighted average return ignores month-to-month variation in assets under management, it measures the net return earned by the fund manager, or equivalently, the buy-and-hold return on a dollar invested over the entire sample period. In contrast, a dollar-weighted return explicitly accounts for net cash flows into and out of the fund over time, reflecting the average investor's performance during the sample period. We measure investor timing ability with a statistic hereafter referred to as the "performance gap", defined as the time-weighted return minus the dollar-weighted return.

The dollar-weighted return measure is particularly well-suited to the focus of this paper because dollar-weighted returns carry the implicit assumption that new cash flows are reinvested over future periods, whereas alternative measures focus only on a single period return, possibly weighting this return with current period cash flow. Specifically, other studies examining investor behavior (e.g. Zheng, 1999; Sapp and Tiwari, 2004]) impute the fund return, or alpha, to the fund investor at a single point in time. These studies implicitly assume that new money is put into the fund for one period, earns the return generated by the fund, and then is immediately taken out. These measures do not track the impact of multiple period returns on a single cash flow. In reality, the current month's positive net cash flows often remain, either in whole or in part, invested in the fund for multiple periods. Moreover, the impact of cash outflows should include not only the current month's missed return, but the opportunity cost of missed returns in future months as well. The dollar-weighted return methodology captures the interaction between all cash flows and returns to a fund over the entire sample period, thus measuring the full impact of investor cash flow timing decisions.

${ }^{1}$ Studies on the timing ability of fund managers include Bollen and Busse (2001), Dellva (2001), Volkman (1999), Daniel et al. (1997), Lee and Rahman (1990), Chang and Lewellen (1984), and Henriksson (1984). Timing ability has also been examined in the context of investment newsletter recommendations (Graham and Harvey, 1996), portfolio managers (Elton and Gruber, 1991) and investment advisors (Kleiman et al., 1996; Cumby and Modest, 1987). 
Prior studies have examined investors' dollar-weighted returns, but none have used cash flows at the individual fund level. For example, Nesbitt (1995) examines timeweighted and dollar-weighted returns at the aggregate level for 17 categories of mutual funds over the 1984-1994 period. He reports that, on average, investors' dollar-weighted annual returns from these categories are $1.08 \%$ less than time-weighted returns. Braverman et al. (2005) examine aggregate mutual fund flows and report that the annual dollarweighted return is significantly lower than the buy-and-hold return over multiple time periods. They speculate that this finding may possibly be due to either time-varying expected returns or investor sentiment.

The use of aggregate cash flow data in these prior studies potentially biases one's inferences about investor behavior for two reasons. First, aggregation of data, and in particular of individual fund net cash flows and returns, which can be either positive or negative, discards potentially important information. ${ }^{2}$ Second, this approach precludes any possibility of investor fund selection ability and does not afford an opportunity to examine possible differential timing performance among various fund clienteles. By using fund-level data, we are able to individually measure the timing performance of investors who choose "good" funds and investors who choose "poor" funds. Thus, the current study contributes to the literature by measuring investor timing ability while also explicitly controlling for any fund selection ability investors may possess. Our fund-level approach also has the benefit of allowing for an extensive analysis of the cross-sectional variation in investor timing performance in order to shed additional light on fund investor behavior.

For the 7,125 equity mutual funds in our sample we compute monthly dollar-weighted returns over 1991-2004 and find that the geometric average monthly return is $0.62 \%$, while the average monthly dollar-weighted return is $0.49 \%$. Thus, investors underperform by about $0.13 \%$ per month, or $1.56 \%$ annually, relative to a buy-and-hold strategy. This performance gap is twice as large for load funds ( $0.16 \%$ per month) as for no-load funds $(0.08 \%$ per month). In order to distinguish between investors based on the quality of fund they choose, we compute the risk-adjusted performance, or alpha, of each fund over the sample period according to both the Fama and French (1993) 3-factor model and the Carhart (1997) 4-factor model. Using either measure, we find that poor investor timing is significantly associated with better-performing funds. More interesting yet, we find that the alpha-gain that is potentially available to investors even in good-performing funds under either benchmark measure is largely erased by the poor timing of investors in these funds. This finding is similar in spirit to the story put forth in Frazzini and Lamont (2006), where investors fail to benefit from superior performance due to entering and exiting at the wrong time.

We document further significant cross-sectional variation in the difference between time-weighted and dollar-weighted returns. The performance gap is found to be largest among the largest quintile of funds in our sample. The size of the performance gap is also

2 To see how this could potentially impact estimation of investor timing performance, consider two funds, $\mathrm{X}$ and $\mathrm{Y}$. Investors in Fund $\mathrm{X}$ display poor timing primarily through positive cash flows to the fund that occur ahead of low returns, thus generating a large measured performance gap for Fund $X$. Investors in Fund $Y$ display poor timing primarily through negative cash flows that occur ahead of high returns, thus generating a large measured performance gap for Fund Y. Upon aggregating the cash flows and returns of these two funds, it is possible that no performance gap at all would be detected in the aggregate data. 
increasing in fund load, turnover, and length of fund history. Overall, the evidence suggests that larger, more costly funds seem to attract less-sophisticated investors.

Analysis of fund style shows that underperformance due to timing is negatively correlated with value-style funds, but is positively associated with momentum-style funds. We find a significant performance gap for both index and non-index funds, indicating that some index fund investors are timing their investments through these low-cost vehicles, though the gap is smaller at $0.05 \%$ per month, versus $0.13 \%$ for non-index funds. We also calculate separately the dollar-weighted returns on positive and negative net cash flows for each fund. We find that on average, poorly timed purchase decisions cost investors about $0.06 \%$ per month and poorly timed withdrawals cost investors approximately $0.15 \%$ per month. We demonstrate through simulation that our empirical results are consistent with investor return-chasing behavior.

Finally, for comparison with equity funds, we examine bond funds and money market funds. We find that the average monthly performance gap over 1991-2004 is much smaller for bond funds at $0.02 \%$, and is nearly flat for money funds at $0.004 \%$. The poor timing phenomenon thus seems to be largely unique to equity mutual funds, suggesting either more sophisticated, or perhaps less active, investors in the bond and money funds.

Our study adds to the growing literature on the behavior and performance of mutual fund investors. By analyzing investor timing at the individual fund level, our methodology preserves cross-sectional differences in the timing performance of investors in individual funds. We not only show that attempts to time the market by fund investors are on average detrimental to investor returns, but we shed light on which fund investors are most likely to exhibit poor timing. Our results are consistent with investor return-chasing behavior. However, it is sobering to reiterate that the performance gap due to poor investor timing largely offsets the value added by actively managed funds in terms of alpha for the subset of funds that does indeed offer a positive alpha. Hence, even investors who select the best funds on average sacrifice the potential benefit due to poor timing of cash flows. Overall, our results commend the relative appeal of a simple "buy-and-hold" strategy to the average investor.

The rest of the paper is organized as follows. Section 2 describes the data and outlines our return measurement and performance benchmarking methodology. Section 3 presents the empirical results on investor timing performance and examines the relationship between fund characteristics and the timing performance gap. Section 4 explores possible explanations for investor return behavior, and Section 5 concludes.

\section{Data and return measurement methodology}

\subsection{Sample description}

Our sample is taken from the CRSP Survivor-Bias Free US Mutual Fund Database, and includes all domestic common stock funds that exist at any time during the period 1991-2004 for which monthly total net assets (TNA) values exist. Funds with fewer than 12 monthly observations are excluded from the sample. We also exclude international, sector, balanced, and specialized funds, as the benchmarking models employed in our cross-sectional analysis may be inappropriate for these funds. Monthly returns are adjusted to account for multiple fund distributions on the same day, as suggested by Elton et al. (2001). 
Since the dollar-weighted return is an internal rate of return measure, it suffers from the multiple solutions problem when monthly fund cash flows repeatedly change sign. However, many of these solutions are either complex numbers or real numbers that are less than $-100 \%$. For the vast majority of funds, there exists only one real root greater than $-100 \%$. Due to the limited liability constraint inherent in a mutual fund investment, we retain only funds with a unique dollar-weighted return above $-100 \%$, which yields a sample of 7125 funds. Unless otherwise noted, all of our analysis is conducted for these 7125 funds. We also note that, for purposes of this study, fund share classes are treated as distinct funds.

Table 1 reports descriptive statistics for the fund sample. The average fund has nearly half a billion dollars under management and experiences monthly net cash flows of $0.65 \%$ of TNA. We also note that average annual fund turnover is $92 \%$ of fund assets, the average total load fee is $2.32 \%$, and the average annual fund expense ratio is $1.42 \%$.

\subsection{Measurement of returns and cash flows}

Denote the return for fund $j$ in month $t$ to be $r_{j t}$. The geometric average monthly return for fund $j$ is calculated as

$$
\bar{r}_{j}^{\mathrm{g}}=\left(\prod_{t=1}^{T}\left(1+r_{j t}\right)\right)^{1 / T}-1
$$

Table 1. Sample statistics

\begin{tabular}{|c|c|c|c|c|c|}
\hline & Mean & Median & $\begin{array}{c}25 \text { th } \\
\text { percentile }\end{array}$ & $\begin{array}{c}\text { 75th } \\
\text { percentile }\end{array}$ & $\begin{array}{l}\text { Standard } \\
\text { deviation }\end{array}$ \\
\hline Total net assets ( $\$$ millions) & 478.94 & 466.33 & 390.85 & 545.47 & 101.84 \\
\hline Monthly net cash flow (\$ millions) & 3.09 & 2.97 & 1.73 & 4.66 & 1.70 \\
\hline Turnover (\%/year) & $91.67 \%$ & $88.44 \%$ & $85.47 \%$ & $96.11 \%$ & $12.58 \%$ \\
\hline Maximum front-end load fee (\%) & $1.51 \%$ & $1.27 \%$ & $1.22 \%$ & $1.70 \%$ & $0.47 \%$ \\
\hline Maximum total load fee (\%) & $2.32 \%$ & $2.26 \%$ & $2.19 \%$ & $2.30 \%$ & $0.20 \%$ \\
\hline Expense ratio (\% / year) & $1.42 \%$ & $1.44 \%$ & $1.36 \%$ & $1.47 \%$ & $0.12 \%$ \\
\hline
\end{tabular}

The table presents summary statistics on the mutual fund sample obtained from the CRSP SurvivorBias Free US Mutual Fund Database. The sample includes all US equity mutual funds that existed at any time during January 1991 through December 2004 for which monthly total net assets (TNA) values exist. Sector funds, international funds, balanced funds and specialized funds are excluded. The final sample contains 7125 funds. The monthly net cash flow for fund $j$ in month $t$ is $\mathrm{NCF}_{j, t}=\mathrm{TNA}_{j}$ ${ }_{t}-\mathrm{TNA}_{j, t-1}\left(1+r_{j, t}\right)$, where, $\mathrm{NCF}_{j, t}$ denotes the monthly net cash flow for fund $j$ in month $t, \mathrm{TNA}_{j, t}$ is the total net assets for fund $j$ at the end of month $t$, and $r_{j, t}$ is the fund's return in month $t$. Turnover is defined as the minimum of aggregate purchases or sales of securities during the year, divided by the average TNA. Maximum front-end load is the maximum percent charges applied at the time of purchase, while maximum total load fees equals maximum front-end load fees plus maximum sales charges paid when withdrawing money from the fund. The expense ratio is the percentage of total investment that shareholders pay for the fund's operating expenses. For each item, we compute the cross-sectional averages in each year from 1991 to 2004. The reported statistics are computed from the time-series of the 14 annual cross-sectional averages for each item. 
Geometric returns are appropriate measures of past fund manager performance, and also measure the average return on a dollar invested during the entire sample period. The dollar-weighted average return measures the return weighted by the amount of money invested at each point in time, and thus captures the average return earned by fund investors. The dollar-weighted average monthly return for fund $j$ is defined as the rate of return at which the accumulated value of the initial TNA, plus the accumulated value of net cash flows, equals the actual TNA at the end of the sample period:

$$
\bar{r}_{j}^{\mathrm{dw}}: \mathrm{TNA}_{0}\left(1+\bar{r}_{j}^{\mathrm{dw}}\right)^{T}+\sum_{t=1}^{T} \mathrm{NCF}_{t}\left(1+\bar{r}_{j}^{\mathrm{dw}}\right)^{(T-t)}=\mathrm{TNA}_{T}
$$

where

$$
\mathrm{NCF}_{j, t}=\mathrm{TNA}_{j, t}-\mathrm{TNA}_{j, t-1}\left(1+r_{j, t}\right)
$$

Here, $\mathrm{NCF}_{j, t}$ denotes the monthly net cash flow for fund $j$ in month $t$ and $\mathrm{TNA}_{j, t}$ is the total net assets for fund $j$ at the end of month $t .^{3}$ All investor cash flows are implicitly assumed to occur discretely at the end of each month. We follow Gruber (1996) and assume that investors in merged funds place their money in the surviving fund and continue to earn the return on the surviving fund. Because the holdings of the investor are identical to the holdings of the fund itself at any point in time, no risk adjustment is necessary in order to measure investor timing. Our measure of investor timing for fund $j$, which we refer to as the performance gap, is computed by subtracting the dollar-weighted return in Equation (2) from the geometric fund return in Equation (1):

$$
\text { Performance } \text { gap }_{j}=r_{j}^{-\mathrm{g}}-r_{j}^{-\mathrm{dw}}
$$

We do note the possibility that some sophisticated investors may shift their portfolio holdings among other asset classes as part of an overall asset allocation or risk-reduction strategy. Any possible effect on overall investor performance from such activity will not be captured by this measure. This timing performance measure simply judges the success of investor cash flows against a buy-and-hold strategy in the respective fund.

\subsection{Measurement of fund performance}

For our cross-sectional analysis of investor timing ability, we wish to classify funds according to their risk-adjusted performance. We evaluate fund performance using two commonly employed benchmark models: the Fama and French (1993) 3-factor model, and a 4-factor model as in Carhart (1997). Specifically, the Fama-French 3-factor model is given by:

$$
r_{p, t}=a_{p}+\beta_{1, p} \mathrm{RMRF}_{t}+\beta_{2, p} \mathrm{SMB}_{t}+\beta_{3, p} \mathrm{HML}_{t}+e_{p, t}
$$

Here, $r_{p, t}$ is the monthly return on fund $p$ in excess of the one month T-bill return; RMRF is the excess return on a value-weighted market portfolio; and SMB and HML are returns on zero-investment factor-mimicking portfolios for size and book-to-market. The Carhart

${ }^{3}$ While this framework for calculating net cash flows is standard in the literature, we also confirm that our results are robust to assuming that cash flows occur at the beginning or middle of the month. Ber and Ruenzi (2006) study the general suitability of using net imputed cash flows as opposed to actual inflows and outflows and conclude that the net cash flow measure serves as an appropriate and unbiased measure. 
4-factor benchmarking model is given by:

$$
r_{p, t}=a_{p}+\beta_{1, p} \mathrm{RMRF}_{t}+\beta_{2, p} \mathrm{SMB}_{t}+\beta_{3, p} \mathrm{HML}_{t}+\beta_{4, p} \mathrm{UMD}_{t}+e_{p, t}
$$

where $r_{p, t}$, RMRF, SMB, and HML are as in the Fama-French 3-factor model, and UMD is the return on the zero-investment factor-mimicking portfolio for one-year momentum in stock returns. For each model, alpha is computed for each fund from all available return data over the sample period, with a minimum of 12 return observations being required for estimation.

\section{Empirical results}

\subsection{Investor timing performance}

We compute arithmetic, geometric and dollar-weighted average returns for each fund in our sample, and the results are reported in Panel A of Table 2. For the average fund, investors earn $0.13 \%$ less per month (1.56\% annually) than the fund itself. For the median fund, the monthly performance gap is $0.11 \%$ ( $1.32 \%$ annually). Panels B and C report average returns for index and non-index funds, respectively. Interestingly, investors in passively managed funds appear to attempt market timing, though we note that the mean monthly performance gap of $0.13 \%$ for actively managed funds is larger than the gap of $0.05 \%$ observed for index funds. Panels D and E report average returns for load and noload funds, respectively. The monthly performance gap of $0.08 \%$ for no-load funds is about half the gap of $0.16 \%$ observed for load funds. Taken together, Panels A-E in Table 2 suggest that mutual fund investors on average underperform their chosen funds by between $1 \%$ and $2 \%$ per year due to the timing of their cash flows.

In order to see whether differences in investor timing ability exist between fund objective categories, we sort funds based on their CRSP SI-Objective variable and report summary statistics for each objective category in Table 3. We find that the performance gap is positive and significant for all six major objective categories, although growth-oriented categories in general have the largest performance gaps while income-oriented funds have the smallest. The largest performance gap is seen for aggressive growth funds at $0.25 \%$ per month $(3.00 \%$ annually), and this category also exhibits the largest cross-sectional variability in fund performance.

A potential concern is that our results may be driven by small funds with relatively fewer assets under management, since each fund receives an equal weight in the reported average regardless of size. If true, then our reported average performance gap need not represent the performance gap for the average dollar invested in equity funds. However, we find that our results are in fact driven by the larger funds in our sample. In Table 4 we report the performance gap when funds are sorted into quintiles based on total assets. The table reveals a monotonic relationship between the performance gap and fund size categories, where underperformance is the largest for the largest quintile of funds. The timing performance gap is significantly positive for all size categories except for the smallest funds, where it is indistinguishable from zero. The largest quintile of funds has an average monthly performance gap of $0.19 \%$ (2.28\% annually).This suggests that a simple average of all funds may actually understate the performance gap on the average dollar invested in equity funds, since the performance gap is greatest among the largest funds. 
Table 2. Fund returns and investor timing performance

\begin{tabular}{|c|c|c|c|c|c|}
\hline & Mean & Median & $\begin{array}{c}\text { 25th } \\
\text { percentile }\end{array}$ & $\begin{array}{c}\text { 75th } \\
\text { percentile }\end{array}$ & $\begin{array}{l}\text { Standard } \\
\text { deviation }\end{array}$ \\
\hline \multicolumn{6}{|l|}{ Panel A: All funds $(n=7,125)$} \\
\hline Arithmetic monthly return & 0.74 & 0.83 & 0.39 & 1.21 & 0.91 \\
\hline Geometric monthly return & 0.62 & 0.69 & 0.24 & 0.11 & 0.96 \\
\hline Dollar-weighted monthly return & 0.49 & 0.62 & 0.02 & 1.07 & 1.02 \\
\hline $\begin{array}{l}\text { Performance gap } \\
(t \text {-stat.) }\end{array}$ & $\begin{array}{c}0.13 \\
(20.70)\end{array}$ & 0.11 & -0.11 & 0.35 & 0.53 \\
\hline \multicolumn{6}{|l|}{ Panel B: Index funds $(n=416)$} \\
\hline Arithmetic monthly return & 0.73 & 0.77 & 0.33 & 1.07 & 0.84 \\
\hline Geometric monthly return & 0.62 & 0.65 & 0.20 & 0.95 & 0.87 \\
\hline Dollar-weighted monthly return & 0.57 & 0.62 & 0.13 & 1.07 & 0.91 \\
\hline Performance gap & 0.05 & 0.06 & -0.21 & 0.28 & 0.45 \\
\hline (t-stat.) & $(2.27)$ & & & & \\
\hline \multicolumn{6}{|l|}{ Panel C: Non-index funds $(n=6,709)$} \\
\hline Arithmetic monthly return & 0.74 & 0.82 & 0.39 & 1.18 & 0.89 \\
\hline Geometric monthly return & 0.60 & 0.68 & 0.24 & 1.06 & 0.94 \\
\hline Dollar-weighted monthly return & 0.47 & 0.59 & 0.01 & 1.04 & 1.01 \\
\hline Performance gap & 0.13 & 0.11 & -0.10 & 0.36 & 0.54 \\
\hline (t-stat.) & $(19.72)$ & & & & \\
\hline \multicolumn{6}{|l|}{ Panel D: Load funds $(n=4,408)$} \\
\hline Arithmetic monthly return & 0.68 & 0.76 & 0.34 & 1.11 & 0.81 \\
\hline Geometric monthly return & 0.53 & 0.63 & 0.19 & 0.98 & 0.84 \\
\hline Dollar-weighted monthly return & 0.38 & 0.50 & -0.07 & 0.95 & 0.94 \\
\hline Performance gap & 0.16 & 0.12 & -0.09 & 0.37 & 0.51 \\
\hline$(t$-stat.) & $(20.83)$ & & & & \\
\hline \multicolumn{6}{|l|}{ Panel E: No-load funds $(n=2,717)$} \\
\hline Arithmetic monthly return & 0.85 & 0.90 & 0.48 & 1.31 & 0.98 \\
\hline Geometric monthly return & 0.70 & 0.76 & 0.34 & 1.20 & 1.05 \\
\hline Dollar-weighted monthly return & 0.63 & 0.73 & 0.20 & 1.20 & 1.09 \\
\hline Performance gap & 0.08 & 0.07 & -0.14 & 0.33 & 0.60 \\
\hline$(t$-stat.) & $(6.95)$ & & & & \\
\hline
\end{tabular}

For each fund, we calculate the average monthly arithmetic, geometric and dollar-weighted returns over the entire sample period. Performance gap is the difference between fund geometric and dollar-weighted returns. Panel A reports statistics on the full sample of funds. Panel B reports returns separately for index funds, while Panel C reports returns for non-index funds. Panel D reports returns for load funds, and Panel E reports returns for no-load funds. $t$-Statistics for the mean performance gap are reported in parentheses. Returns are percent per month.

\subsection{Fund alphas and the timing performance gap}

By measuring investor timing ability at the individual fund level we are able to examine whether there is any apparent relationship between timing performance and the quality of the fund selected by an investor. For this purpose we compute a risk-adjusted return, or alpha, according to both the Fama and French (1993) 3-factor and Carhart (1997) 4 -factor benchmark models for each fund over the sample period. Using this measure of fund quality, we then sort all funds into deciles based on the alpha measure of fund performance. 


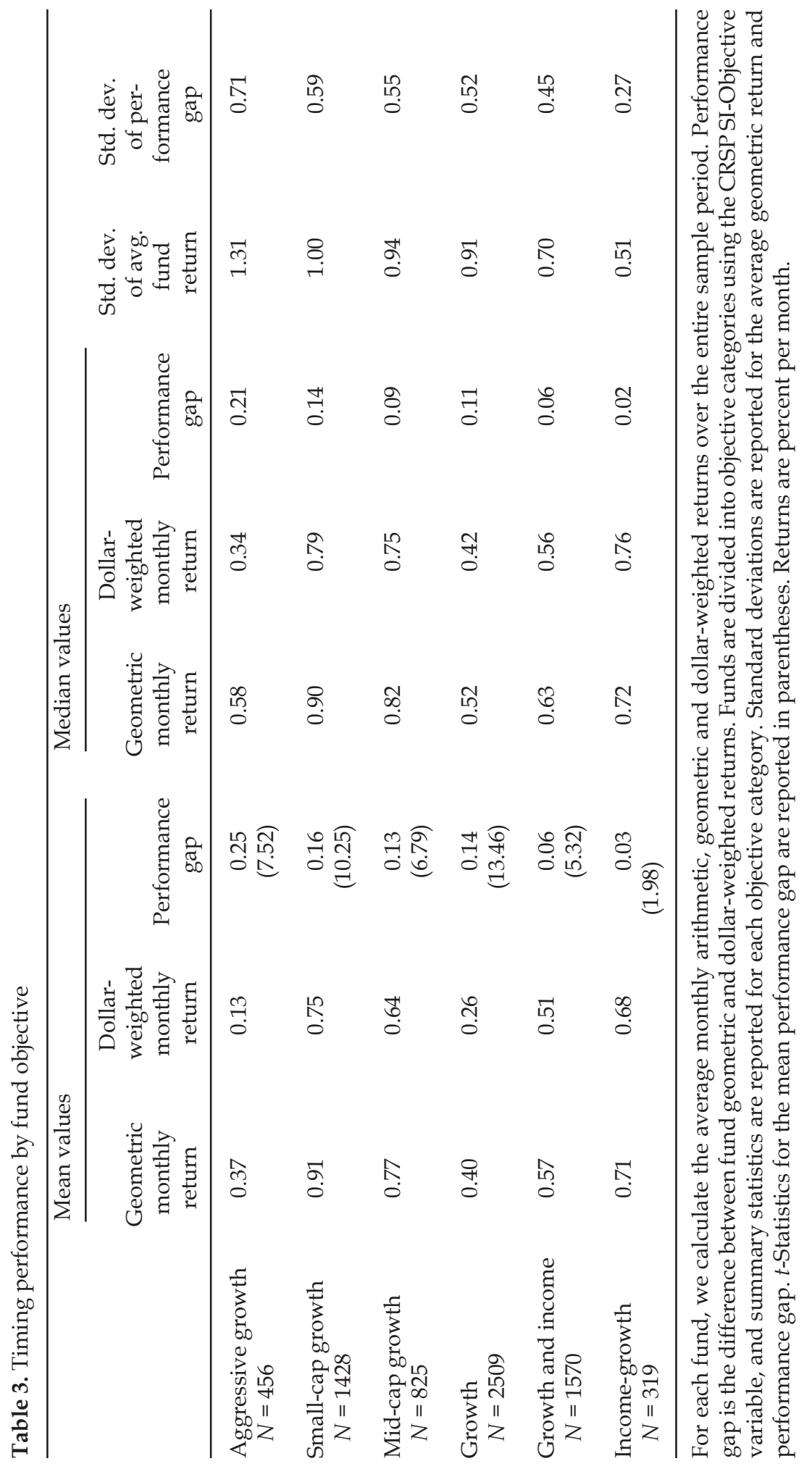


Table 4. Timing performance by fund size

\begin{tabular}{lccccc}
\hline \multicolumn{1}{c}{$\begin{array}{c}\text { (small) } \\
\text { Quintile 1 }\end{array}$} & Quintile 2 & Quintile 3 & Quintile 4 & (large) \\
Quintile 5 \\
\hline Average TNA (millions) & 1.30 & 8.56 & 30.70 & 100.79 & 1251.65 \\
Arithmetic return & 0.58 & 0.65 & 0.74 & 0.84 & 0.91 \\
Geometric return & 0.44 & 0.51 & 0.59 & 0.69 & 0.76 \\
Dollar-weighted return & 0.43 & 0.39 & 0.45 & 0.52 & 0.57 \\
Performance gap & 0.01 & 0.12 & 0.14 & 0.17 & 0.19 \\
$(t$-stat.) & $(0.77)$ & $(8.69)$ & $(11.42)$ & $(13.29)$ & $(17.67)$ \\
\hline
\end{tabular}

For each fund, we calculate the average monthly arithmetic, geometric and dollar-weighted returns over the entire sample period. Performance gap is the difference between fund geometric and dollar-weighted returns. Funds are divided into quintiles based upon average total net assets (TNA). The cross-sectional averages for each TNA-based quintile are reported. Quintile 1 contains the smallest funds and quintile 5 contains the largest funds. Returns are percent per month.

Panel A of Table 5 sorts funds by 3-factor alpha and reports the mean 3-factor alpha and performance gap for each decile. We first of all note that the timing performance gap is positive and significant for all deciles of alpha-sorted funds. The average annual 3-factor alpha for all funds in the sample is $-0.18 \%$ per month $(-2.18 \%$ annually), and only the top three deciles of funds have an average alpha that is positive. The relationship between investor timing underperformance and the risk-adjusted performance of the fund is quite strong, with a Spearman rank correlation of 0.84 , significant at the $1 \%$ level. For the decile of best performing funds, the 3-factor alpha is an impressive $0.57 \%$ per month, but this subset of funds also has the largest performance gap at $0.38 \%$ per month due to poor cash flow timing by investors. We also separately report the average alpha and average performance gap for the subset of 1902 funds that has a positive alpha. It is interesting to note that the alpha-gains of $0.27 \%$ per month offered by these good-performing funds is largely offset by average investor underperformance of $0.25 \%$ per month due to poor timing decisions. ${ }^{4}$

Panel B of Table 5 ranks funds into deciles according to the 4-factor alpha performance measure and reports the mean 4-factor alpha and performance gap for each decile of funds. Controlling for stock return momentum has no material effect on the results, which are nearly indistinguishable from those of the 3-factor analysis in Panel A. Investors in the better-performing funds again exhibit the poorest cash flow timing, which to a large extent offsets the superior performance offered by these funds. For the 1918 funds that generate a positive alpha, the potential gain of $0.23 \%$ per month is only slightly larger than the average investor underperformance of $0.18 \%$ per month due to poor cash flow timing.

\subsection{Determinants of the performance gap}

We have conducted several univariate sorts of the data which have revealed some interesting features of investor timing underperformance. We now analyze the determinants of the performance gap controlling for a number of fund characteristics such as fund age, size, expenses, load, turnover, level of cash flow, volatility, and a measure of overall performance. For each fund, the mean level of each fund characteristic over the sample period is employed. Model I in Table 6 includes among the regressors the mean return of the fund

${ }^{4}$ Note that alpha is computed as an arithmetic return whereas timing underperformance is computed from geometric returns. Therefore, a comparison of the two measures is only approximate and suggestive. 
Table 5. Timing performance for deciles formed on fund alpha

\begin{tabular}{|c|c|c|c|}
\hline $\begin{array}{l}\text { 3-Factor alpha } \\
\text { performance decile }\end{array}$ & 3-Factor alpha & $\begin{array}{l}\text { Timing } \\
\text { performance gap }\end{array}$ & $\begin{array}{l}\text { Timing } \\
\text { performance gap } t \text {-stat. }\end{array}$ \\
\hline \multicolumn{4}{|c|}{ Panel A: Performance ranked on 3-factor alpha } \\
\hline 1 Worst & -0.993 & 0.068 & 2.42 \\
\hline 2 & -0.512 & 0.080 & 4.65 \\
\hline 3 & -0.369 & 0.054 & 3.34 \\
\hline 4 & -0.277 & 0.036 & 2.29 \\
\hline 5 & -0.201 & 0.076 & 5.02 \\
\hline 6 & -0.131 & 0.094 & 5.92 \\
\hline 7 & -0.061 & 0.146 & 8.98 \\
\hline 8 & 0.015 & 0.171 & 9.04 \\
\hline 9 & 0.139 & 0.166 & 7.99 \\
\hline 10 Best & 0.571 & 0.378 & 14.19 \\
\hline All funds & -0.182 & 0.127 & \\
\hline Alpha $>0$ funds $(N=1,902)$ & 0.273 & 0.252 & \\
\hline Spearman rank correlation & $0.84 * * *$ & & \\
\hline $\begin{array}{l}\text { 4-Factor alpha } \\
\text { performance decile }\end{array}$ & 4-Factor alpha & $\begin{array}{l}\text { Timing } \\
\text { performance gap }\end{array}$ & $\begin{array}{l}\text { Timing } \\
\text { performance gap } t \text {-stat. }\end{array}$ \\
\hline \multicolumn{4}{|c|}{ Panel B: Performance ranked on 4-factor alpha } \\
\hline 1 Worst & -0.971 & 0.110 & 3.98 \\
\hline 2 & -0.520 & 0.092 & 4.70 \\
\hline 3 & -0.369 & 0.118 & 6.11 \\
\hline 4 & -0.273 & 0.079 & 4.59 \\
\hline 5 & -0.197 & 0.118 & 7.06 \\
\hline 6 & -0.129 & 0.120 & 7.05 \\
\hline 7 & -0.061 & 0.103 & 6.56 \\
\hline 8 & 0.017 & 0.136 & 8.42 \\
\hline 9 & 0.120 & 0.164 & 8.36 \\
\hline 10 Best & 0.487 & 0.228 & 8.87 \\
\hline All funds & -0.190 & 0.127 & \\
\hline Alpha $>0$ funds $(N=1,918)$ & 0.233 & 0.182 & \\
\hline Spearman rank correlation & 0.76 ** & & \\
\hline
\end{tabular}

Panel A reports the mean alpha and mean performance gap for deciles of funds sorted on 3-factor alpha. Panel B reports the mean alpha and mean performance gap for deciles of funds sorted on 4-factor alpha. Three-factor and 4-factor alphas are estimated for each fund according to Equations (5) and (6), respectively, in the text using all available fund returns in the sample period. All returns are percent per month. ** Significant at the $5 \%$ level. *** Significant at the $1 \%$ level.

over the sample period as a measure of performance. Model II replaces the raw return with the fund 3-factor alpha as a measure of performance, and Models III and IV adopt the 4-factor alpha as a performance measure. Model IV also includes the estimated factor loadings for size, book-to-market, and momentum in order to control for fund style.

Results show that the size of the performance gap is increasing in fund load fees, turnover, and length of return history, although the significance of turnover is generally marginal. The positive relation between timing underperformance and fund turnover is particularly intriguing, since both dollar-weighted and geometric returns are measured net of expenses and trading costs. The evidence indicates that older and more expensive funds are associated with an investor clientele that is especially poor at cash flow timing. Fund 
Table 6. Determinants of the performance gap

\begin{tabular}{|c|c|c|c|c|}
\hline & Model I & Model II & Model III & Model IV \\
\hline Intercept & $\begin{array}{c}-0.446 \\
(-9.95)\end{array}$ & $\begin{array}{l}-0.118 \\
(-2.69)\end{array}$ & $\begin{array}{l}-0.152 \\
(-3.45)\end{array}$ & $\begin{array}{c}-0.104 \\
(-2.36)\end{array}$ \\
\hline Number of returns & $\begin{array}{c}0.001 \\
(5.54)\end{array}$ & $\begin{array}{r}0.001 \\
(4.50)\end{array}$ & $\begin{array}{c}0.001 \\
(4.93)\end{array}$ & $\begin{array}{c}0.001 \\
(5.25)\end{array}$ \\
\hline Average TNA & $\begin{array}{c}0.001 \\
(0.54)\end{array}$ & $\begin{array}{c}0.001 \\
(0.48)\end{array}$ & $\begin{array}{c}0.001 \\
(0.53)\end{array}$ & $\begin{array}{l}0.000 \\
(0.05)\end{array}$ \\
\hline Average fund expenses & $\begin{array}{c}3.167 \\
(1.31)\end{array}$ & $\begin{array}{l}2.133 \\
(0.83)\end{array}$ & $\begin{array}{l}1.607 \\
(0.61)\end{array}$ & $\begin{array}{l}1.504 \\
(0.56)\end{array}$ \\
\hline Average total load & $\begin{array}{l}0.978 \\
(2.85)\end{array}$ & $\begin{array}{c}0.785 \\
(2.24)\end{array}$ & $\begin{array}{c}0.824 \\
(2.31)\end{array}$ & $\begin{array}{c}0.782 \\
(2.18)\end{array}$ \\
\hline Average turnover & $\begin{array}{c}0.009 \\
(1.94)\end{array}$ & $\begin{array}{c}0.011 \\
(2.30)\end{array}$ & $\begin{array}{c}0.011 \\
(2.29)\end{array}$ & $\begin{array}{c}0.009 \\
(1.86)\end{array}$ \\
\hline Average net cash flow ( $\%$ of TNA) & $\begin{array}{c}-0.001 \\
(-0.62)\end{array}$ & $\begin{array}{l}-0.001 \\
(-0.86)\end{array}$ & $\begin{array}{l}-0.001 \\
(-0.83)\end{array}$ & $\begin{array}{c}-0.001 \\
(-0.80)\end{array}$ \\
\hline Average return & $\begin{array}{c}13.387 \\
(11.03)\end{array}$ & & & \\
\hline Standard deviation of returns & $\begin{array}{c}7.094 \\
(10.01)\end{array}$ & $\begin{array}{c}1.143 \\
(1.40)\end{array}$ & $\begin{array}{l}1.750 \\
(2.07)\end{array}$ & $\begin{array}{l}0.604 \\
(0.74)\end{array}$ \\
\hline 3-Factor alpha & & $\begin{array}{l}13.690 \\
(4.36)\end{array}$ & & \\
\hline 4-Factor alpha & & & $\begin{array}{c}9.978 \\
(3.19)\end{array}$ & $\begin{array}{c}8.993 \\
(2.70)\end{array}$ \\
\hline SMB factor loading & & & & $\begin{array}{l}-0.054 \\
(-1.80)\end{array}$ \\
\hline HML factor loading & & & & $\begin{array}{c}-0.083 \\
(-2.89)\end{array}$ \\
\hline UMD factor loading & & & & $\begin{array}{c}0.118 \\
(1.99)\end{array}$ \\
\hline 3-Factor tracking error & & $\begin{array}{c}0.050 \\
(4.22)\end{array}$ & & \\
\hline 4-Factor tracking error & & & $\begin{array}{c}0.054 \\
(4.03)\end{array}$ & $\begin{array}{c}0.064 \\
(4.52)\end{array}$ \\
\hline Adj. $R^{2}$ & 0.083 & 0.059 & 0.050 & 0.057 \\
\hline
\end{tabular}

For each equity mutual fund, we calculate the difference between geometric and dollar-weighted returns, which we label the fund's performance gap. The performance gap is the dependent variable in a linear regression on the fund characteristics listed in the first column of the table. 3-Factor and 4-factor alphas are estimated for each fund according to Equations (5) and (6), respectively, in the text using all available fund returns in the sample period. The regression coefficients are reported with White heteroskedasticityconsistent $t$-statistics in parentheses.

volatility, especially non-market volatility, is seen to be positively correlated with timing underperformance. We later discuss how investor return-chasing behavior can explain this finding. We note that neither fund size nor average net cash flow are significant predictors of timing performance after controlling for other fund characteristics. The fact that the level of fund net cash flows has no marginal explanatory power for the performance gap suggests that the overall rate of non-investment growth of the fund is irrelevant to investor timing performance. Load funds are typically purchased with the help of a broker or investment advisor, and our evidence suggests that those investors who are most likely relying on advice from a broker perform especially poorly from a timing standpoint. This is consistent with Bergstresser et al. (2006), who find that brokers typically fail to deliver any tangible benefits to their clientele. 
Table 6 also confirms that the performance gap is greatest in funds with the best performance, whether measured by raw returns or by either the 3-factor or 4-factor benchmark. This is an interesting finding, because it tells us that there is no necessary connection between being able to select good funds and timing investment cash flows well. In fact the evidence is quite the opposite: investors who select a good fund are nevertheless plagued by particularly poor timing of their cash flows. Finally, we note that a size-based fund style is not correlated with the performance gap, although underperformance due to timing is negatively correlated with value-style funds and is positively associated with momentum-style funds. The finding that investors poorly time cash flows into momentum-style funds is consistent with return-chasing behavior, an issue we further explore below.

\subsection{An alternative measure of investor timing ability}

To further examine the source of timing underperformance exhibited by investors, we separately calculate the dollar-weighted returns on positive and negative cash flows to each fund. Using this approach we are able to separate the effect of net purchase and withdrawal decisions in order to determine whether these have a differential impact on investor timing performance. An additional feature of this approach is that fund total assets are ignored and investor dollar-weighted returns are therefore unaffected by changes in fund size that are due to fund returns. Thus, calculating investor returns separately for positive and negative cash flows also serves as a robustness check on our earlier results. On the other hand, care must be taken in handling these returns because the dollar amounts of positive and negative cash flow from which they are respectively derived may differ substantially.

Note that investors with positive timing ability will systematically invest more money prior to high return periods, producing a dollar-weighted return on positive net cash flows that exceeds the geometric average return. They will also systematically withdraw funds prior to low return periods, generating a dollar-weighted return on negative net cash flows that is less than the fund's geometric average return. From the investor's perspective, high dollar-weighted returns are desirable for positive cash flows, while low dollar-weighted returns are desirable for negative cash flows. In particular, the average return generated by the fund serves as the relevant benchmark against which we compare the average investor returns on positive and negative cash flows.

Define, $\mathrm{NCF}_{j, t}^{+} \equiv \max \left(\mathrm{NCF}_{j, t}, 0\right)$ and $\mathrm{NCF}_{j, t}^{-} \equiv \min \left(\mathrm{NCF}_{j, t^{\prime}} 0\right)$. The dollar-weighted return on positive net cash flows only, $r_{j}^{-\mathrm{dw},+}$, is defined as

$$
\bar{r}_{j}^{\mathrm{dw},+}: \sum_{t=1}^{T} \mathrm{NCF}_{j, t}^{+}\left(1+\bar{r}_{j}^{\mathrm{dw},+}\right)^{(T-t)}=\sum_{t=1}^{T}\left(\mathrm{NCF}_{j, t}^{+} \prod_{s=t+1}^{T}\left(1+r_{j, s}\right)\right)
$$

and the dollar-weighted return on negative net cash flows, $r_{j}^{-\mathrm{dw},-}$, is defined as

$$
\bar{r}_{j}^{\mathrm{dw},-}: \sum_{t=1}^{T} \mathrm{NCF}_{j, t}^{-}\left(1+\bar{r}_{j}^{\mathrm{dw},-}\right)^{(T-t)}=\sum_{t=1}^{T}\left(\mathrm{NCF}_{j, t}^{-} \prod_{s=t+1}^{T}\left(1+r_{j, s}\right)\right)
$$

Table 7 reports the dollar-weighted return calculated separately for positive and negative net cash flows, according to Equations (7) and (8). We find that the dollar-weighted return on positive net cash flows is $0.56 \%$ per month for the average fund, while the dol- 
Table 7. Investor returns by signed cash flow

\begin{tabular}{lccccc}
\hline & Mean & Median & $\begin{array}{c}\text { 25th } \\
\text { percentile }\end{array}$ & $\begin{array}{c}75 \text { th } \\
\text { percentile }\end{array}$ & $\begin{array}{c}\text { Standard } \\
\text { deviation }\end{array}$ \\
\hline $\begin{array}{l}\text { Dollar-weighted return on } \\
\quad \text { positive net cash flows }\end{array}$ & 0.56 & 0.63 & 0.11 & 1.12 & 1.04 \\
$\begin{array}{l}\text { Dollar-weighted return on } \\
\quad \text { negative net cash flows }\end{array}$ & 0.77 & 0.80 & 0.29 & 1.40 & 1.35 \\
$\begin{array}{l}\text { Difference (positive - negative) } \\
(t \text {-stat.) }\end{array}$ & -0.21 & -0.14 & -0.53 & 0.13 & 0.95 \\
\hline
\end{tabular}

lar-weighted average return on negative net cash flows is $0.77 \%$. Thus the average new dollar invested earned $0.56 \%$ per month, while the average dollar withdrawn would have earned $0.77 \%$ had it remained in the fund, representing an unfavorable overall difference of $0.21 \%$ in monthly return. Moreover, comparing each to the average fund return of $0.62 \%$, we see that poorly timed purchase decisions cost investors about $0.06 \%$ per month and poorly timed withdrawals cost investors approximately $0.15 \%$ per month. Overall, poor investor withdrawal decisions hurt investors more than poor purchase decisions, though both clearly play a role in investor underperformance.

This table reports statistics on fund dollar-weighted average monthly returns computed separately on positive and negative net cash flows for the full sample of equity funds. Statistics for the difference in positive and negative cash flow returns is also reported. These returns are calculated according to Equations (7) and (8) in the text. Returns are percent per month.

One possible explanation of these results is that investors respond to poor fund performance by withdrawing assets, behaving in a manner consistent with the limits-of-arbitrage story of Shleifer and Vishny (1997). In their model, investors withdraw money after negative returns, thereby irrationally selling assets that are in fact undervalued. It is also possible that investor withdrawals are liquidity motivated, and that investor liquidity needs are most acute in periods where fund returns are poor. In either case, we can state that investors systematically withdraw funds prior to relatively good performance, and these withdrawals reduce investor returns.

\subsection{Timing performance by year}

In order to shed light on whether investor timing performance differs by time period or is sensitive to the length of fund return history, we estimate and report fund geometric and investor dollar-weighted returns on a calendar year basis. Only funds having 12 monthly returns in a given year are included in the sample for the year, and returns for the fund are computed only based on the 12 months of data for the year. Results are reported in Table 8 for each year of the sample as well as for all fund-years.

Since the mutual fund industry was growing throughout the 1991-2004 sample period, the least number of funds (296) appears in 1991, and the greatest number of funds (3765) appears in 2004. Of the 14 years in our sample, the performance gap is positive and significant in all but three-1995, 1997, and 2003 - which presents no discernable pattern over time. Thus, it appears that investors tend to underperform a buy-and-hold strategy in all manner of market conditions. We also note that the dollar-weighted return on negative cash flows exceeds the dollar-weighted return on positive cash flows in all years ex- 


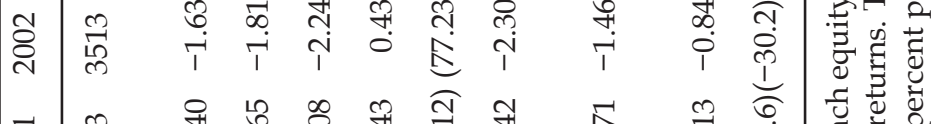

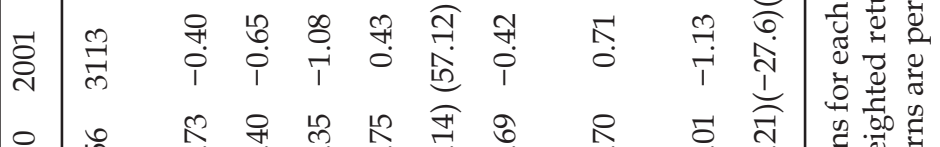

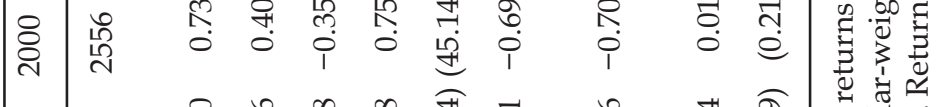

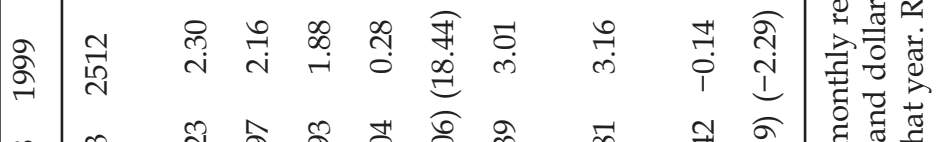

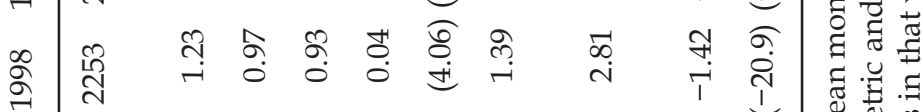

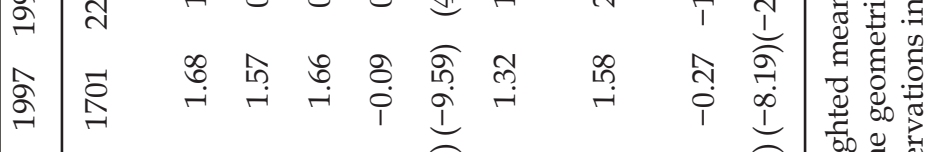

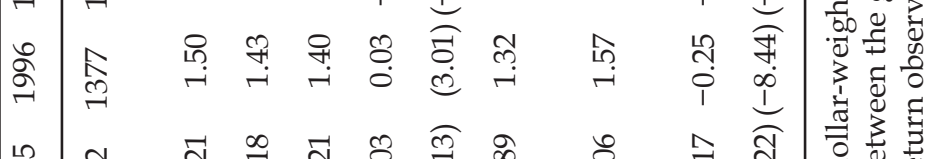

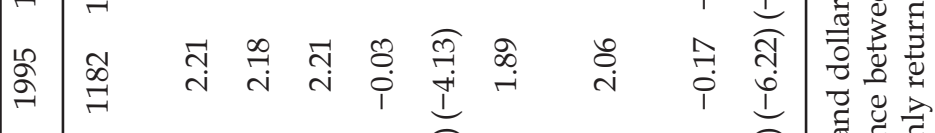

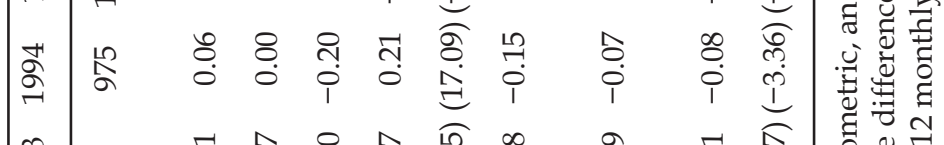

$$
\begin{aligned}
& \text { \& }
\end{aligned}
$$

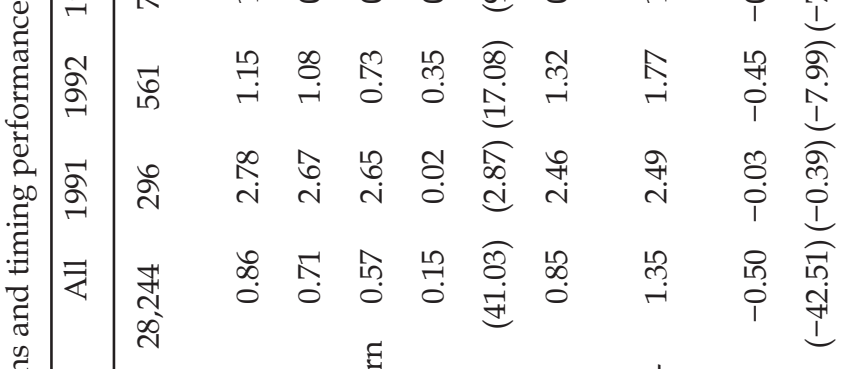

$$
\begin{aligned}
& \text { 全 }
\end{aligned}
$$

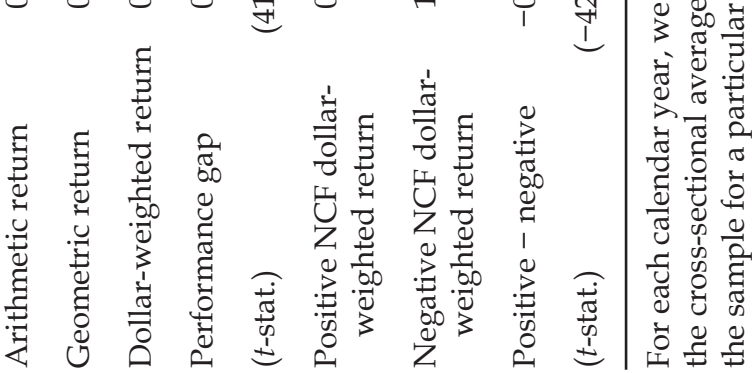


cept 2000, and in that year the difference is not significantly different from zero. This indicates that poor cash withdrawal decisions are consistently more detrimental to investor timing performance than poorly timed cash flows into funds.

In the regression analysis in Table 6 we noted that a longer return history is associated with a larger performance gap. The fact that the performance gap is positive in most years, including the early years of the sample, explains why a longer return history is correlated with a larger performance gap: there is simply more time to accumulate losses. This implies that funds with longer return histories will generally have a greater influence on reported sample means. Furthermore, the yearly computation of returns allows us to gauge the extent of any possible effect. Specifically, by pooling all 28,244 fund-years of data computed by this method we obtain an average monthly performance gap of $0.15 \%$, which is nearly identical to our previously reported value of $0.13 \%$ when using all available data for each fund. To summarize, whether we compute and weight returns by fund or by fund-year, we find that the overall performance gap is approximately the same.

\section{Exploring investor behavior}

\subsection{Return-chasing and the performance gap}

The empirical finding of a pervasive timing performance gap is consistent with a behavioral explanation where fund investors simply chase large recent returns and flee from low recent returns. Timing underperformance may occur even if investors are able to identify funds that on average outperform their peers and is likely due to a combination of the weak persistence in fund returns and investor failure to rebalance at the right time. Intuitively speaking, if fund returns are serially uncorrelated and investors buy in following returns far above the mean while taking cash out following returns far below the mean, they will on average lose due to the tendency of outcomes to cluster at the mean. Even in the presence of some weak return persistence, investors may over-estimate their ability to exploit this persistence. If active investors do not rebalance at the right times, they can still suffer inferior performance due to poor cash flow timing.

Numerous studies in the experimental psychology literature demonstrate that individual cognitive biases are often state dependent. For example, overconfidence tends to be most pronounced in situations where information is ambiguous and predictability is low (Griffn and Tversky, 1992) and the task is of moderate to extreme difficulty (Fischoff et al., 1982). Overconfident investors over-estimate the precision of their information, trade too frequently, and as a result experience poor investment performance (Odean, 1998).

Kahneman and Tversky (1972) examine the representativeness heuristic, defined as a subjective judgment of the extent to which an event is similar in essential properties to the parent population. They demonstrate that individuals often over-estimate the degree to which a single event is similar to the parent population. Mutual fund investors who exhibit the representativeness heuristic will over-estimate the predictability of fund returns, believing that a single large return is indicative of a fund with a high mean return. This could lead to return-chasing behavior and generate a performance gap between investor returns and the returns of the underlying fund.

Evidence on fund return volatility and fund style is consistent with the behavioral hypothesis just described. Specifically, the results reported in Table 3 on the volatility of average returns for the funds sorted by investment objective show a strong positive cor- 
relation between return volatility and the performance gap. We also note that in the regressions in Table 6, fund total volatility and tracking error are both significant predictors of timing underperformance. Regarding fund style, in Table 6 timing underperformance was found to be significantly correlated with momentum style funds. Momentum style funds have greater recent return persistence than other funds and may serve as a stronger inducement for investors to attempt timing. While consistent with a behavioral explanation, we note that this evidence is only suggestive. To explore the issue further, we next present simulation evidence that is also suggestive of a return-chasing explanation for timing underperformance.

\subsection{Simulation evidence}

In this section, we use simulated data to study how our measures of performance vary for different specifications of investor behavior. We simulate a sample of 7,125 funds with 36 monthly return observations each. Monthly returns are calibrated to correspond to the average return in our actual data sample and are assumed to be independent draws from a normal distribution with mean return $0.75 \%$ and standard deviation of $5 \%$. Net cash flows are assumed to occur at the end of each month. The net cash flow, as a percentage of the end-of-month TNA (after returns), is determined by one of five specifications. All specifications consist of a random liquidity component for fund $j$ in month $t, \varepsilon_{j t} \sim N(0, s$. $d .=1 \%)$. In addition, specifications $2-5$ consist of a behavioral component. The sensitivity of cash flows to returns employed in each model was calibrated through regression using the mutual fund sample. ${ }^{5}$ Let

$$
\begin{aligned}
& I^{+}=\left\{\begin{array}{ll}
1 & \text { if } r_{j t-1}>0.75 \%, \\
0 & \text { otherwise }
\end{array} \text { and } I^{-}= \begin{cases}1 & \text { if } r_{j t-1} \leq 0.75 \% \\
0 & \text { otherwise }\end{cases} \right. \\
& \text { Specification 1: } \quad \mathrm{NCF}_{j t}=\varepsilon_{j t} \\
& \text { Specification 2: } \quad \mathrm{NCF}_{j t}=\varepsilon_{j t}+3\left(r_{j t-1}-0.0075\right) \\
& \text { Specification 3: } \quad \mathrm{NCF}_{j t}=\varepsilon_{j t}+3\left(r_{j t-1}-0.0075\right) \cdot I^{+} \\
& \text {Specification 4: } \quad \mathrm{NCF}_{j t}=\varepsilon_{j t}+3\left(r_{j t-1}-0.0075\right) \cdot I^{-} \\
& \text {Specification 5: } \quad \mathrm{NCF}_{j t}=\varepsilon_{j t}-3\left(r_{j t-1}-0.0075\right)
\end{aligned}
$$

Under specification 1, net cash flows are random. End-of-month net cash flows are correlated with the prior month's return under specification 2 , so that investors make positive investments in funds with above average returns, and withdraw money from funds experiencing below average returns. The magnitude of the cash flow is directly proportional to the difference between the actual return and the average return. In specification 3 , investors chase hot funds, but net cash flows are random for funds with poor returns. Investors flee from poor performers under Specification 4, but cash flows to hot funds are random. Specification 5 simulates a contrarian strategy, where investors sell funds af-

${ }^{5}$ For each fund, we regress percentage net cash flow on lagged mean-centered returns. The average cross-sectional coefficient from these regressions is 3.06, thus motivating our choice of 3.0 for the performance-cash flow sensitivity coefficient on lagged returns in (9b) through (9e). 
Table 9. Returns and performance gaps for simulated return data

\begin{tabular}{lcccccc}
\hline & Actual & \multicolumn{5}{c}{ Simulated data } \\
\cline { 6 - 7 } & data & Scenario 1 & Scenario 2 & Scenario 3 & Scenario 4 & Scenario 5 \\
\hline Geometric average return & 0.62 & 0.63 & 0.63 & 0.63 & 0.63 & 0.63 \\
Dollar-weighted return & 0.49 & 0.63 & 0.28 & 0.47 & 0.48 & $1.02 \%$ \\
$\begin{array}{l}\text { Performance gap } \\
(t \text {-stat.) }\end{array}$ & 0.13 & -0.00 & 0.35 & 0.16 & 0.15 & -0.39 \\
Dollar-weighted return on & $(20.70)$ & $(-0.93)$ & $(94.07)$ & $(52.91)$ & $(21.25)$ & $(-98.50)$ \\
positive net cash flows & 0.56 & 0.60 & 0.41 & 0.40 & 0.52 & 0.82 \\
$\begin{array}{l}\text { Dollar-weighted return on } \\
\text { negative net cash flows }\end{array}$ & 0.77 & 0.60 & 0.61 & 0.59 & 0.66 & 0.60 \\
$\begin{array}{l}\text { Difference (positive - negative) } \\
(t \text {-stat.) }\end{array}$ & -0.21 & -0.00 & -0.20 & -0.19 & -0.13 & 0.22 \\
\hline & $(-19.55)$ & $(-0.35)$ & $(-81.32)$ & $(-51.18)$ & $(-41.68)$ & $(100.28)$ \\
\hline
\end{tabular}

Returns are simulated for 7,125 funds with 36 monthly return observations per fund. Independent monthly returns are drawn from a normal distribution with mean $0.75 \%$ and standard deviation $5 \%$. Initial fund assets (TNA $_{0}$ equal 10,000 for each fund. Subsequent net assets are calculated endogenously using simulated returns and net cash flows, with $\mathrm{TNA}_{j t}=\mathrm{TNA}_{j(t-1)}\left(1+r_{j t}\right)+\mathrm{NCF}_{j t}$, where $r_{j}$ is fund $j^{\prime}$ s return in month $t$, and $\mathrm{NCF}_{j t}$ is the end-of-month net cash flow for fund $j$ in month $t$. In Scenario 1, monthly net cash flows as a percentage of TNA are equal to a random liquidity component with mean zero and standard deviation 1\%. Monthly net cash flows in the four behavioral scenarios (Scenarios 2-5) consist of the same random liquidity component plus a behavioral component. The behavioral components are as follows. Scenario 2: symmetric return-chasing behavior in which the behavioral net cash flow component equals 3 times the difference between the fund's lagged monthly return and its mean return; Scenario 3: positive return-chasing behavior only, in which the behavioral component is zero if the fund's lagged monthly return is below the mean and equal to 3 times the difference between the lagged return and the mean return if the difference is positive; Scenario 4: negative return-fleeing behavior, in which the behavioral component is zero if the fund's lagged return is above the mean and equal to 3 times the difference between the lagged return and the mean return if the difference is negative; Scenario 5: contrarian behavior in which the behavioral component is equal to -3 times the difference between the lagged return and the mean return. Returns are percent per month.

ter above average returns, and buy funds after below average returns. Total net assets for each fund are calculated using the simulated monthly returns and net cash flows. ${ }^{6}$

Table 9 reports summary statistics for the average fund return, average investor dollarweighted return, and the performance gap. In addition, we calculate the dollar-weighted returns on the signed cash flows and report the difference. With random returns and net cash flows (specification 1), the performance gap is zero, as is the difference between positive and negative cash flow returns. The performance gap is positive for the three momentum based strategies in specifications 2-4, indicating poor timing ability, and is negative for the contrarian strategy, indicating positive timing ability. In addition, the difference between returns on positive and negative net cash flows is negative for specifications 2-4, indicating that the average opportunity cost of withdrawn funds exceeds the average return earned on new investments. Results which most closely approximate the actual data are those in Specification 4, where investors flee from low returns, but cash flows to good-

${ }^{6}$ Total net assets at the beginning of the simulation (TNA ${ }_{0}$ ) is set to 10,000 for each fund. Subsequent monthly total net asset values are calculated endogenously using the simulated returns and net cash flows, with $\mathrm{TNA}_{j t}=\mathrm{TNA}_{j(t-1)}\left(1+r_{j t}\right)+\mathrm{NCF}_{j t}$, where $r_{j t}$ is fund $j^{\prime}$ s return in month $t$, and $\mathrm{NCF}_{j t}$ is the end-of-month net cash flow for fund $j$ in month $t$, specified in (9b), (9c), (9d) and (9e) above. 
Table 10. Bond fund and money fund returns

\begin{tabular}{|c|c|c|c|c|c|}
\hline & Mean & Median & $\begin{array}{l}\text { 25th } \\
\text { percentile }\end{array}$ & $\begin{array}{c}\text { 75th } \\
\text { percentile }\end{array}$ & $\begin{array}{l}\text { Standard } \\
\text { deviation }\end{array}$ \\
\hline \multicolumn{6}{|l|}{ Panel A: Bond funds } \\
\hline Arithmetic monthly return & 0.44 & 0.44 & 0.35 & 0.53 & 0.29 \\
\hline Geometric monthly return & 0.43 & 0.44 & 0.34 & 0.52 & 0.30 \\
\hline Dollar-weighted monthly return & 0.41 & 0.41 & 0.31 & 0.51 & 0.34 \\
\hline $\begin{array}{l}\text { Performance gap } \\
\text { (t-stat.) }\end{array}$ & $\begin{array}{c}0.02 \\
(9.44)\end{array}$ & 0.02 & -0.02 & 0.07 & 0.18 \\
\hline \multicolumn{6}{|l|}{ Panel B: Money market funds } \\
\hline Arithmetic monthly return & 0.24 & 0.25 & 0.16 & 0.32 & 0.13 \\
\hline Geometric monthly return & 0.24 & 0.25 & 0.16 & 0.32 & 0.14 \\
\hline Dollar-weighted monthly return & 0.24 & 0.23 & 0.13 & 0.32 & 0.13 \\
\hline $\begin{array}{l}\text { Performance gap } \\
\text { (t-stat.) }\end{array}$ & $\begin{array}{c}0.004 \\
(4.18)\end{array}$ & 0.0007 & -0.01 & 0.02 & 0.05 \\
\hline
\end{tabular}

Bond and Money Market fund datasets include all domestic bond and money market funds in the CRSP Survivor-Bias Free US Mutual Fund Database with returns over the 1991-2004 period. The bond sample consists of 7,222 funds, while the money market sample contains 2,730 funds. For each fund, we calculate the average monthly arithmetic, geometric and dollar-weighted returns over the entire sample period. Performance gap is the difference between fund geometric and dollar-weighted returns. Panel A reports statistics for the sample of bond funds. Panel B reports statistics for money market funds.

performing funds are random. This would also seem consistent with stylized evidence in the literature that poor performance persistence is more easily recognized than superior performance. Overall, the simulation results in Table 9 show that investor return-chasing behavior is broadly consistent with the negative timing ability and performance gap found empirically.

\subsection{Timing performance in alternative asset classes}

Our analysis so far has focused on the timing ability of equity fund investors, for which we have documented substantial underperformance. However, these results may not necessarily extend to other asset classes having different return and risk characteristics. For comparison with equity fund investors, in this section we examine investor timing ability for two alternative asset classes - bond funds and money market funds.

The bond fund sample consists of all domestic bond funds in the CRSP Survivor-bias Free Mutual Fund database with a unique dollar-weighted average return over the 19912004 period. ${ }^{7}$ There are 7222 such funds with an average TNA of \$228 million, an average load of $2.40 \%$, and average annual expenses of $1.05 \%$. The sample of money market funds includes 2730 funds with unique dollar-weighted average returns over the 1991-2004 period, with an average TNA of $\$ 825$ million, an average load of $0.26 \%$, and average annual expenses of $0.60 \%$. Performance results are reported in Table 10.

We find that there is a smaller performance gap among bond funds. We also note that the average bond fund returns are much lower than the opportunity cost of withdrawn equity funds. Specifically, the average geometric return among bond funds is $0.43 \%$ per month, while the average dollar-weighted return is $0.41 \%$, producing an average monthly

${ }^{7}$ We again note that individual fund share classes are treated as distinct funds for purposes of this study. 
performance gap of $0.02 \%$. Moreover, the dollar-weighted return on positive bond cash flows is $0.42 \%$ per month, while the return on negative bond cash flows is only slightly higher, at $0.45 \%$, which again indicates only modest mis-timing. Similar results are found for money market funds, where the average performance gap is only $0.002 \%$ per month. The average return on positive cash flows is slightly higher than the return on negative cash flows (2.54\% vs. $2.45 \%$ annually).

Overall, the average performance gap is small among bond funds and flat among money market funds, suggesting that negative timing is largely a phenomenon exhibited by equity fund investors. In light of the relatively lower return volatility for bond and money market funds, these results are also consistent with the behavioral story presented earlier.

\section{Conclusions}

Our study examines the timing ability of mutual fund investors using cash flow data at the individual fund level. We do this by computing the dollar-weighted return earned by investors in each individual fund over the period 1991-2004 and find that the average active fund investor substantially underperforms the growth of a dollar invested in the fund over the entire measurement period. This phenomenon is not only significant for the entire sample but is also found to be robust across various sub-categories of funds whether sorted by size, objective, or risk-adjusted performance. As demonstrated through simulation, this timing underperformance is consistent with investor return-chasing behavior. Furthermore, a comparison of the performance of index fund investors to that of non-index fund investors shows that both groups substantially underperform due to poor timing decisions. This suggests that a significant number of investors who have decided to take a passive approach to security selection by indexing are not necessarily passive in the timing of their cash flows, perhaps preferring a pure timing strategy through this low-cost vehicle.

Certain fund characteristics such as load fees, turnover, and age are directly correlated with an underperforming active investor clientele. It may be the case that more-sophisticated investors are able to locate newer funds to move into as they become available, whereas older and larger funds enjoy significant patronage due to name-brand or a lessmobile or captive investor clientele. Most interesting, however, is the finding that investors who select the best performing funds also exhibit the worst timing performance of all. Thus return-chasing can be a costly endeavor, even when a good fund is found.

Overall, our results suggest that a note of caution is in order for fund investors who are considering whether to attempt market timing. Rather than outperforming a given fund, the average active investor is more likely to underperform a passive dollar invested in the fund. In fact, given the magnitude of average underperformance of new cash flows we have documented, losses from poor market timing decisions likely would erase any potential gains from investing in an otherwise superior fund.

\section{References}

Ber and Ruenzi, 2006 - Ber, S., and Stefan, R., 2006. On the usability of synthetic measures of mutual fund net-flows. Center for Financial Research Working Paper 06-05.

Bergstresser et al., 2006 - Bergstresser, D., Chalmers, J., and Tufano, P., 2006. Assessing the costs and benefits of brokers in the mutual fund industry, Working Paper.

Bollen and Busse, 2001-Bollen, N. P., and Busse, J. A. On the timing ability of mutual fund managers, Journal of Finance 56 (2001), pp. 1075-1094.

Braverman et al., 2005 - Braverman, O., Kandel, S., and Wohl, A., 2005. The (Bad?) Timing of mutual 
fund investors, Working Paper.

Carhart, 1997 - Carhart, M. On persistence in mutual fund performance, Journal of Finance 52 (1997), pp. $57-82$.

Chang and Lewellen, 1984- Chang E. C., and Lewellen, W. G. Market timing and mutual fund investment performance, Journal of Business 57 (1984), pp. 57-72.

Cumby and Modest, 1987 - Cumby, R. E., and Modest, D. M. Testing for market timing ability, Journal of Financial Economics 19 (1987), pp. 169-189.

Daniel et al., 1997 - Daniel, K., Grinblatt, M., Titman, S., and Wermers, R. Measuring mutual fund performance with characteristic-based benchmarks, Journal of Finance 52 (1997), pp. 1035-1058.

Dellva, 2001 - Dellva, W. L. Selectivity and market timing performance of fidelity sector mutual funds, Financial Review 36 (2001), pp. 39-54.

Elton and Gruber, 1991 - Elton, E. J., and Gruber, M. J. Differential information and timing ability, Journal of Banking and Finance 15 (1991), pp. 117-131.

Elton et al., 2001 - Elton, E. J., Gruber, M. J., and Blake, C. A first look at the accuracy of the CRSP mutual fund database and a comparison of the CRSP and Morningstar mutual fund databases, Journal of Finance 56 (2001), pp. 2415-2430.

Fama and French, 1993 - Fama, E., and French, K. Common risk factors in the return on bonds and stocks, Journal of Financial Economics 33 (1993), pp. 3-53.

Fischoff et al., 1982- Fischoff, B., Slovic, P., and Lichtenstein, S. Calibration of probabilities: The state of the art to 1980. In: D. Kahneman, P. Slovic, and A. Tversky, Editors, Judgement under Uncertainty: Heuristics and Biases, Cambridge University Press, Cambridge (1982).

Frazzini and Lamont, 2006 - Frazzini, A., and Lamont, O., 2006. Dumb money: Mutual fund flows and the cross-section of stock returns. NBER Working Paper w11526.

Graham and Harvey, 1996- Graham, J. R., and Harvey, C. R. Market timing ability and volatility implied in investment newsletters' asset allocation recommendations, Journal of Financial Economics $\mathbf{4 2}$ (1996), pp. 397-421.

Griffn and Tversky, 1992- Griffn, D., and Tversky, A. The weighing of evidence and the determinants of confidence, Cognitive Psychology 24 (1992), pp. 411-435.

Gruber, 1996 - Gruber, M. Another puzzle: The growth in actively managed mutual funds, Journal of Finance 51 (1996), pp. 783-810.

Henriksson, 1984- Henriksson, R. D. Market timing and mutual fund performance: An empirical investigation, Journal of Business 57 (1984), pp. 73-96.

Ippolito, 1992- Ippolito, R. Consumer reaction to measures of poor quality: Evidence from the mutual fund industry, Journal of Law and Economics 35 (1992), pp. 45-70.

Kahneman and Tversky, 1972- Kahneman, D., and Tversky, A. Subjective probability: A judgment of representativeness, Cognitive Psychology 3 (1972), pp. 430-454.

Kleiman et al., 1996 - Kleiman, R. T., Sahu, A. P., and Callaghan, J. H. The risk-adjusted performance of investment advisors: Empirical evidence on selectivity and timing abilities, Journal of Economics and Finance 20 (1996), pp. 87-98.

Lee and Rahman, 1990- Lee, C., and Rahman, S. Market timing, selectivity and mutual fund performance: An empirical investigation, Journal of Business 63 (1990), pp. 261-278.

Nesbitt, 1995 - Nesbitt, S. Buy high, sell low: Timing errors in mutual fund allocations, Journal of Portfolio Management 22 (1995), pp. 57-60.

Odean, 1998 - Odean, T. Volume, volatility, price and profit when all traders are above average, Journal of Finance 53 (1998), pp. 1887-1934.

Sapp and Tiwari, 2004- Sapp, T., and Tiwari, A. Does stock return momentum explain the "smart money" effect?, Journal of Finance 59 (2004), pp. 2605-2622.

Shleifer and Vishny, 1997- Shleifer, A., and Vishny, R. The limits of arbitrage, Journal of Finance 52 (1997), pp. 35-55.

Volkman, 1999- Volkman, D. A. Market volatility and perverse timing performance of mutual fund managers, Journal of Financial Research 22 (1999), pp. 449-470.

Zheng, 1999 - Zheng, Lu. Is money smart? A study of mutual fund investors' fund selection ability, Journal of Finance 54 (1999), pp. 901-933. 